\title{
СОРТОВА РЕАКЦІЯ НА ФОРМУВАННЯ НАСІННЄВОЇ ПРОДУКТИВНОСТІ КАРТОПЛІ ПРИ ОБРОБЦІ ПОСІВІВ РЕГУЛЯТОРАМИ РОСТУ
}

\author{
Кабанець Віктор Михайлович \\ доктор сільськогосподарських наук, доцент, директор \\ Інститут сільського господарства Північного Сходу НААН України, с. Сад, Україна \\ ORCID: 0000-0002-5981-7184 \\ agronauka@gmail.com
}

Оничко Віктор Іванович

кандидат сільськогосподарських наук, доцент Сумський національний аграрний університет, м. Суми, Україна

ORCID: 0000-0003-0584-319X

onichko@gmail.com

Музика Леонід Пилипович

кандидат сільськогосподарських наук, старший науковий співробітник Інститут сільського господарства Північного Сходу НААН України, с. Сад, Україна agronauka@gmail.com

Бердін Сергій Іванович кандидат сільськогосподарських наук, доцент, доцент Сумський національний аграрний університет, м. Суми, Україна ORCID: 0000-0002-2337-4107 serdantes00@ gmail.com

Якість насіннєвого матеріалу будь-якої сільськогосподарської культури є основою їі врожайності. Враховуючи значну вартість посадкових бульб картоплі, збільшення коефіцієнту розмноження насіння високих генерацій є фрактором зниження собівартості посадкового матеріалу. Використання стимулятору росту дозволяє не тільки збільшити вихід насіннєвих бульб з одиниці площі, а і вирішити це екологічно безпечним шляхом. Враховуючи значну кількість рістстимулючих препаратів та їх чутливість до грунтово-кліматичних умов у разі застосування, актуальним є проведення широкого спектра зональних досліджень по підбору більш ефрективних стимуляторів росту.

У дослідженнях, що проводились в Інституті сільського господарства Північного Сходу НААН України, вивчалась біологічна реакція сортів картоплі Скарбниия, Щедрик, Слов'янка на позакореневу обробку посівів регуляторами росту Агрінос Д, Вегестим, РК, Вимпел-К (Агролайт-У) і Гумати (Гуміфрілд ВР-18, Фульвітал Плюс). Об'єктом досліджень виступали процеси формування насіннєвої продуктивності картоплі під дією зазначених препаратів.

Встановлено, що в умовах північно-східного Лісостепу є позитивний вплив усіх препаратів, що досліджувались, на формування насіннєвої продуктивності. Виявленні особливості реакиії сортів на формування складових насіннєвої продуктивності. Середній у сорту вихід насіннєвих бульб був у межах від 40,5 \% у сорту Щедрик і до 45,9 \% у сорту Скарбниия. Застосування Гуматів у більшості випадків суттєво збільшувало насіннєву продуктивність, але в структурі врожайності їх вага значно поступалася контролю.

Слід зазначити, що посадковий матеріал картоплі більшою мірою доцільно розглядати не з точки зору вагових показників, а кількості бульб придатних для висадки. Як показали дослідження, при застосуванні стимуляторів росту фрракційний склад під дією препаратів у середньому по досліду збільшувався у бік насіннєвих бульб від 1,7% (Вимпел-К) до 3,5% (Агрінос Д) та у крупної фрракції - від 1,5% (Агрінос Д) до 5,3% (Гумати).

У розрізі сортів більшу прибавку насіннєвих бульб сформували посіви, які були оброблені Гуматами. Сортом, який позитивно не відреагував на застосування препаратів, був сорт Слов'янка. Максимальне збільшення коефріцієнту розмноження у нього відзначалось при обробці Гуматами (2,0), а при застуванні Вимпел-К (Агролайт-У) рослини зменшили показник виходу насінневих бульб відносно контролю.

У результаті проведених досліджень закономірно узагальнити, що застосування регуляторів росту в посівах картоплі в умовах північно-східного Лісостепу позитивно впливає на збільшення насіннєвої продуктивності, як у вагових, так і у кількісних параметрах. При застосуванні препаратів виявлена різна реакція сортів на вид препарату. Більш суттєво на фрормування посадкового матеріалу виявилась система обробки посівів із застосуванням комплексу Гуматів. Меншою мірою на позакореневу обробку посівів регуляторами росту реагував сорт Слов'янка.

Ключові слова: картопля, врожайність, фракції насіння, кількість бульб, маса бульб.

DOI https://doi.org/10.32845/agrobio.2021.3.4 
Вступ. В останні десятиріччя спостерігаються різкі зміни метеорологічних факторів, які негативно впливають на розвиток рослин картоплі, особливо в період бульбоутворення. Це призводить до посилення процесу виродження картоплі. Ситуація поглиблюється скороченням обсягів виробництва насіннєвого матеріалу високих репродукцій. Важливим заходом одержання високих врожаїв $€$ використання якісного насіннєвого матеріалу.

Тенденція екологізації виробництва сільськогосподарських культур спонукала до створення та впровадження нових, стійких до хвороб сортів і підвищила зацікавленість до використання економічно вигідних ефективних заходів підвищення врожайності - біологічно-активних речовин - регуляторів росту рослин, що дає можливість спрямованої регуляції процесів росту та розвитку рослин картоплі завдяки можливості використання (на відміну від традиційних добрив, як у період передпосівної підготовки посівного матеріалу, так і для позакореневої обробки рослин в оптимальні (найбільш відповідальні) фази їх росту й розвитку.

У сучасних умовах важливим чинником стабілізації галузі картоплярства $€$ налагодження насінництва та ефективне використання насіннєвих бульб, формування організованого ринку як продовольчої, так і насіннєвої картоплі. Використання якісного сортового насіння картоплі $€$ одним з основних заходів підвищення ефективності картоплярства. За даними численних досліджень частка селекційно-насінницьких досягнень у підвищенні врожайності та поліпшенні якості картоплі становить 20-50 \% (Butenko, 2018).

Для зниження негативної дії вірусних хвороб розроблена і застосовується система безвірусного насінництва, одним з елементів якої $€$ біотехнологія. Однак, отриманий біотехнологічними методами вихідний матеріал картоплі досить високовартісний, тому розробка заходів по якомога кращому використанню його продуктивного потенціалу є досить актуальною для підвищення рівня забезпечення споживачів якісним посадковим матеріалом.

Картоплярство - чи не єдина галузь агропромислового комплексу України, обсяги виробництва якої суттєво не змінились протягом останніх 70 років. У цей же час біля 98 \% загального виробництва картоплі - це продукція вирощена на невеликих фермерських, присадибних та дачних ділянках, що вносить свої корективи в технологію вирощування. Щорічні площі картоплі в Україні становлять 1,4-1,5 млн.га, а валове виробництво 18-20,5 млн. т - біля 6 \% світового об'єму (п'яте місце у світі після Китаю, Росії, Індії та США) при врожайності 12,0-13,9 т/га, що значно нижче від біологічних можливостей культури.

Основні причини низької врожайності картоплі це: неякісний посадковий матеріал (порушення принципу сортооновлення та своєчасної сортозаміни), недотримання сівозміни, нестача та неефективне використання добрив, засобів захисту рослин, недотримання основних умов технології. Базовими напрямками збільшення врожайності і виробництва картоплі є: поліпшення технології вирощування (Barabolja \& Ljashenko, 2018), основ- ною ланкою якої є чітка система насінництва (Bilins'ka et al., 2021), впровадження у виробництво нових сортів (M'jalkovs'kij et al., 2021), сортової агротехніки та використання високопродуктивного садивного матеріалу (Medvedeva \& Kostjukevich. 2020; Korshunov et al., 2018). Таким чином виробництво картоплі тримається на «трьох китах»: вибір сорту, високий рівень насінництва і технологія. Водночас вони нерівноцінні за значенням для отримання продукції. Ключовим $€$ сорт. Доведено, що за останніх 25 років внесок нових сортів у підвищенні врожайності картоплі в Європейських країнах сягає 57 \%.

Сучасні економічні умови в аграрному секторі спонукають до пошуку технологій, побудованих на мобілізації дешевих мінеральних та органічних ресурсів (Baybulatov et al., 2018; Atanaw, 2021). При відносно слабкому розвитку кореневої системи рослини картоплі нагромаджують велику вегетативну і бульбову масу, тому у порівнянні з іншими культурами вони більш вимогливі до забезпечення ґрунту поживними речовинами (Muleta \& Aga, 2019). і кращою $€$ така система удобрення, яка забезпечує рослини картоплі ними рівномірно впродовж всієї вегетації.

Отримати високий врожай картоплі допомагає підготовка посадкового матеріалу. Ранній інтенсивний ріст коренів у початковий період розвитку рослин дозволяє краще використати весняну вологу і забезпечити формування бульб, коли температура ґрунту не настільки висока. Тому поряд з передпосадковим обігрівом і пророщуванням бульб значну увагу слід приділяти обробці їх розчинами мікроелементів, добрив і регуляторів росту рослин (Smirnova et al., 2021). Останніми роками в картоплярстві все більша увага приділяється використанню регуляторів росту з метою посилення процесу бульбоутворення, підвищенню стійкості рослин у період вегетації до екстремальних погодних умов - таких, як високі температури та нестача вологи, а також ураження хворобами (Araujo et al., 2019).

Передпосадкова обробка бульб та обробка рослин у період вегетації розчинами регуляторів росту стимулює ріст і розвиток рослин картоплі, збільшує висоту рослин, кількість стебел та асиміляційну поверхню листя, вміст у ньому хлорофілу, підвищує продуктивність фотосинтезу. Під впливом препаратів збільшується кількість бульб, маса однієї бульби, що призводить до збільшення раннього врожаю на 16-33 \%, загального на 10-54 \% в залежності від сорту, генерації та дотримання технології (Uromova et al., 2019).

Дослідженнями, проведеними в Інституті картоплярства НААН, встановлено, що передпосадкова обробка бульб картоплі біопрепаратами Фітоцид і Планриз позитивно впливала на збільшення врожайності. Так, за другого строку садіння (29-30 квітня) приріст врожайності раннього сорту Скарбниця становив відповідно 4,7 і 7,1 т/га, а середньораннього сорту Оберіг - на 0,9 та 5,9 т/га. При використанні препарату Планриз приріст маси стандартних бульб склав 11,8 \% у сорту Скарбниця і 5,1 \% у сорту Оберіг. Загальні втрати врожаю при зберіганні картоплі зменшились на 7,5 та 8,8 \% відповідно (Koltunov et al., 2012) 
При вирощуванні картоплі в умовах центрального Лісостепу України на фоні органічних, мінеральних добрив і сидератів відмічено значне підвищення їх ефективності при обробці бульб перед садінням та вегетуючих рослин у фразі бутонізації розчинами Біолану і Чаркору, що виявляється у посиленні ростових процесів, збільшенні стеблостою і листової поверхні в агрофітоценозі i, в кінцевому результаті, у зростанні врожайності картоплі. У сортів Серпанок, за середньої врожайності у варіантах з добривами 153,6 ц/га і Слов'янка - 183,5 ц/га при обробці бульб Чаркором перед садінням та рослин у фазі бутонізації приріст становив 23,9 і 27,6 ц/га, Біоланом - 21,3 і 24,1 ц/га відповідно (Moloc'kij et al., 2009). Дослідженнями проведеними в умовах Лісостепу Правобережного найперспективнішою виявилась обробка рослин регуляторами росту Емістим С у фазі сходів - сорти Дніпрянка і Поляна (Polishhuk, 2021).

Дослідженнями О. М. Барковського та В. С. Куценко (Інститут картоплярства НААН України) встановлено, що сорти картоплі по різному реагують на обробку бульб захисностимулюючими препаратами, особливо якщо вони різних груп стиглості (Barkovs'kij \& Kucenko, 1999). Регулятори росту рослин досить широко використовують при розмноженні та оздоровленні насіннєвого матеріалу картоплі (Morozov et al., 2018; Milyokhin et al., 2020).

Регулятори росту рослин доцільно використовувати для прискореного розмноження оздоровлених in vitro рослин картоплі, що підвищує їх стійкість до негативних факторів навколишнього середовища (заморозки, засуха, стресовий стан після обробки пестицидами та ін. і шкодочинних організмів) (Trembic'ka et al., 2020). Оптимізувати параметри куща і агрофітоценозу та процес бульбоутворення, а також підвищити адаптаційні можливості рослин, що в кінцевому результаті забезпечить одержання високого врожаю картоплі можна завдяки обробці оздоровлених in vitro рослин картоплі регулятором росту Вимпел у поєднанні з іншими ефективними агрозаходами (Kovalenko \& Olijnik 2016). При цьому приріст урожайності відбувається насамперед завдяки кількості та ваги бульб під одним кущем (Grossi et al., 2020).

Дослідженнями ряду наукових установ установлено, що застосування регуляторів росту рослин на посівах картоплі сприяє росту і розвитку рослин, підвищенню врожайності та поліпшенню стійкості рослин до несприятливих факторів, негативного впливу гербіцидів, підвищенню ефективності добрив (Kovalenko et al., 2007). У дослідах Інституту картоплярства НААН України відмічено позитивний вплив регуляторів росту рослин здатних повністю нейтралізувати фітотоксичну дію гербіцидів. Аналогічні дослідження, проведені науковому центрі землеробства МСГ Республіки Вірменія, показали високу ефективність поєднання гербіцидів з фріторегулятором, який сприяв зняттю фрітотоксичної дії гербіцидів, покращенню росту і розвитку рослин, підвищенню врожайності. (Agaronjan et al., 2020). За даними досліджень, проведених в умовах Передкам'я Республіки Татарстан, додавання до суспензій і розчинів протруйників, регуляторів росту рослин, стимулює природний імунітет рослин до хвороб, внаслідок чого норми витрат пестицидів мож- ливо зменшити у два рази без зниження ефективності захисної дії (Prishhepenko, 2020).

За даними досліджень Інституту сільського господарства Північного Сходу НААН України використання мікродобрив дозволяє істотно поліпшити ріст та розвиток рослин, якість продукції та врожайність вирощуваних культур (Kabanec' et al., 2013). У сучасних кризових умовах, коли більшість виробників не мають можливості забезпечити достатній рівень використання добрив, особливо гостро стоїть питання впровадження у виробництво, в тому числі і в дрібнотоварних (фермерські, присадибних і дачних) господарствах, нових ресурсоощадних елементів і заходів вирощування картоплі з метою підвищення врожайності та поліпшення якості продукції при мінімальній кількості ресурсів. У цьому відношенні надзвичайно актуальним для виробництва $€$ застосування нових, порівняно недорогих (з розрахунку на одиницю площі), засобів підвищення врожайності - регуляторів росту і розвитку рослин. (Semenchuk, 2018), що дає можливість спрямованої регуляції процесів росту і розвитку рослин картоплі завдяки можливості використання, як в період передпосадкової підготовки посівного матеріалу, так і позакореневої обробки рослин у оптимальні (найбільш відповідальні) фрази їх розвитку (Wróbel et al., 2017). Таким чином, вміле використання, регуляторів росту рослин дозволяє не лише помітно підвищити врожай, поліпшити його якість, а й істотно підвищити стійкість рослин до хвороб і стресових факторів, які все більше проявляються останнім часом. За використання рістстимулюючих речовин при вирощуванні картоплі численними дослідженнями відмічено посилення життєздатності рослин, підвищення їх стійкості до несприятливих кліматичних факторів, стресів, зменшення ураження вірусними захворюваннями та пошкодження колорадським жуком, дротяником, поліпшення біохімічного складу і товарної якості бульб (Juzjuk, 2017).

Матеріали і методи досліджень. Дослідження по вивченню сортової реакції картоплі на застосування регуляторів росту проводили згідно програми наукових досліджень (ПНД) НААН України на 2016-2020 рр. 17 Науково-методичне та аналітичне забезпечення інноваційної моделі розвитку галузі картоплярства за завданням 17.00.03.19 П «Підвищення продуктивності насіннєвого матеріалу картоплі, оздоровленого біотехнологічним методом в умовах північно-східного регіону України» упродовж 2019-2020 років в умовах північно-східного Лісостепу України в Інституті сільського господарства Північного Сходу НААН України.

При проведенні досліджень було передбачено використати оздоровлений біотехнологічним методом насіннєвий матеріал трьох сортів картоплі селекції Інституте картоплярства НААН : Щедрик, Скарбниця і Слов'янка. Кількість облікових рослин кожного сорту 50 шт., схема садіння - $70 \times 25$ см, повторність в досліді триразова. Площа облікової ділянки - 8,75 м².

У досліджені були використані такі регулятори росту рослин:

1. Агрінос Д - вільні амінокислоти - $10 \%$ + хітин + хітозан + глюкозамін - 6 \% (компанія «Агрінос», Норвегія); 
2. Вегестим, РК - Емістим С 78 г/л, Івін - 2 г/л ПЕГ 200-60 г/л, ПЕГ - 400-60 г/л, ПЕГ - 600-60 г/л + мікроелементи у хелатній формі: В - 0,3 г/л, Со - 0,024 \%, $\mathrm{Cu}-0,9 \%, \mathrm{Zn}-0,9 \%, \mathrm{Fe}-2,4$ г/л, Mn - 2,4 г/л, Mo - 0,06 \%, Mg - 3,24 \% (ЗАТ «Високий врожай», Україна);

3. Вимпел-К (Агролайт-У), в.р. - ПЕГ-400 - 230 г/л, ПЕГ-1500 - 540 г/л, гумат натрію - 30 г/л, бурштинова кислота - 3 г/л (НДП «Долина», Україна);

4. Гуміфілд ВР-18 - калієва сіль гумінових кислот 20-200 г/л (ТОВ «Агротехносоюз», Україна);

5. Фульвітал Плюс - фульвові кистоти - 20-85 \%, $\mathrm{S}-6 \%$, B $-0-15 \%$, Co $-0-0,5 \%, \mathrm{Cu}-0-15 \%$, Fe 0-4 \%, Mn - 0-5\%, Mo - 0-1\%, Mg - 0,7\%, амінокислоти 0-100 г/кг, бурштинова кислота - 0-100 г/кг, арахідинова кислота - 0-100 г/кг (ТОВ «Агротехносоюз», Україна);

Останні препарати (Гуміфілд ВР-18 та Фульвітал Плюс) застосовувалися в єдиній схемі та мали загальну назву Гумати.

Внесення регуляторів росту під час вегетації рослин картоплі проводили за допомогою ранцевого обприскувача «Ера» з нормою внесення робочої рідини з розрахунку 300 л/га.

Схема застосування регуляторів росту, їх норми та строки обробки наведені у табл. 1.

Закладання досліду, його розміщення в натурі було проведено згідно 3 «Методичними рекомендаціями щодо проведення досліджень з картоплею» (Kucenko et al., 2002) з урахуванням усіх вимог методики дослідної справи за Б. О. Доспєховим (Dospehov, 1985). Повторність в дослідах триразова, площа облікової ділянки 8,75 м² $^{2}$ а схемами розміщення рослин 70 × 25 см. Ґрунт дослідної ділянки - чорнозем типовий малогумусний середньо суглинковий, орний шар якого характеризується наступними основними показниками: вміст гумусу $-4,1 \%, \mathrm{pH}$ сольове - 6,3, сума ввібраних основ 31 мг-екв., вміст рухомих форм фосфору - 11,3 мг/100 г ґрунту, обмінного калію - 9,2 мг/100 г ґрунту, вміст легкогідролізованого азоту за Корнфілдом - 11,2 мг/100 г.

Метеорологічні умови відіграють важливу роль у формуванні врожаю картоплі. Зазначена культура має два критичних періоди, які залежно від перебігу метеорологічних фракторів можуть стати вирішальними для ії рівня врожайності та насіннєвої продуктивності. Такими періодами $€$ «бутонізація» та «формування бульб». Оптимальними для періоду садіння-сходи є: середньодобова температура повітря $18-22^{\circ} \mathrm{C}$, а сума ефективних температур в цей період не повинна перевищувати $\left.565-593^{\circ} \mathrm{C}\right]$. Формування високих врожаїв картоплі відбувається при середньодобовій температурі повітря $16-18^{\circ} \mathrm{C}$, при підвищенні її до $20^{\circ} \mathrm{C}$ уповільнюються процес бульбоутворення, а при $29^{\circ} \mathrm{C}$ і вище - повністю припиняється].

Слід зазначити, що в цілому погодні умови періоду вегетації картоплі в 2019-2020рр. були малосприятливі для росту і розвитку рослин їі та отримання достатньо високого врожаю. За температурним режимом в усі періоди росту і розвитку рослин картоплі (крім періоду садіння-сходи) було відмічено перевищення оптимального рівня (табл. 2). Особливо несприятливі умови склались у періоди «сходи-бутонізація» та «бутонізація-цвітіння» коли за оптимальних у ці періоди 79 мм та 100 мм опадів у 2019 році випало лише 13,3 мм та 0 мм відповідно (для ранньостиглих сортів) та 12,5 і 4,3 мм - (для середньостиглих). Гідротермічний коефіцієнт у ці періоди не перевищував 0,3, що характеризує їх як вкрай посушливі. У 2020 році в цей період умови були дещо кращі. Середня температура в період «бутонізація - цвітіння» у 2019 році знаходилась на рівні $23,8-26,7^{\circ} \mathrm{C}$ і 2020 році $-26,2-24,0^{\circ} \mathrm{C}$ (гідротермічний коефіцієнт відповідно 0,1-0,3), що значно уповільнювало процес бульбоутворення.

Попередник картоплі - озима пшениця. Агротехніка культури включала лущення стерні на глибину 5-8 см у два сліди по діагоналі дисковими лущильниками після збирання попередника. Осінню оранку в другій декаді жовтня проводили на глибину 27-29см. Весняний обробіток закриття вологи боронами ЗБТ-1,0 в два сліди та передпосівна культивація на 14-16 см. Внесення добрив по 4 ц/га нітроамофоски $\left(\mathrm{N}_{60} \mathrm{P}_{60} \mathrm{~K}_{60}\right)$ з послідуючою заробкою їх культиватором. Підготовку насіннєвих бульб до висаджування розпочинали за 4-5 тижнів. Густота висаджування бульб 57,1 тис шт. на гектар за схемою 70 × 25 см. Глибина 6-8 cм від верхівки бульб до верхівки гребеня.

Перший міжрядний обробіток проводили культиватором КОН-2,8 на 7-й день після садіння. Вдруге посіви обробляли через 6-7 днів після першого обробітку. При появі сходів картоплі та досягнення ними висоти 2-5 см проводили їх присипання. За висоти рослин 12-15 см посів обробляли розчином гербіциду Тівітус 25 в.г. Позакореневі підживлення рослин картоплі розчинами

Схема досліду по вивченню сортової реакції на формування насіннєвої продуктивності картоплі при обробці посівів регуляторами росту, 2019-2020 рр.

\begin{tabular}{|c|c|c|c|}
\hline $\begin{array}{c}\text { Назва } \\
\text { варіантів досліду }\end{array}$ & № варіанту & $\begin{array}{c}\text { Назва препарату } \\
\text { та норми використання } \\
\end{array}$ & Строки обробки \\
\hline $\begin{array}{c}\text { Без проведення позакореневих обробок рослин } \\
\text { контроль }\end{array}$ & 1 & Обробка рослин водою & $\begin{array}{c}\text { у відповідні фрази } \\
\text { застосування препаратів }\end{array}$ \\
\hline \multirow{6}{*}{ Застосування стимуляторів росту рослин } & 2 & Агрінос Д (2 л/га) & \multirow{2}{*}{$\begin{array}{c}\text { початок бутонізації } \\
\text { цвітіння }\end{array}$} \\
\hline & 3 & Вегестим, РК, (0,3 л/га) & \\
\hline & 4 & $\begin{array}{c}\text { Вимпел-К (Агролайт-У) } \\
\text { (0,3 л/га) }\end{array}$ & $\begin{array}{l}\text { початок бутонізації } \\
\text { цвітіння }\end{array}$ \\
\hline & \multirow{3}{*}{5} & $\begin{array}{c}\text { Гумати } \\
\text { Гуміфілд ВР-18 (0,4 л/га) }\end{array}$ & за висоти рослин 5-10 см \\
\hline & & Фульфітал Плюс (0,4 л/га) & змикання міжрядь \\
\hline & & Гуміфрілд ВР-18 (0,4 л/га) & в період бутонізації \\
\hline
\end{tabular}


рістрегулюючих речовин проводили згідно з програмою досліджень у відповідні періоди росту та розвитку рослин. Враховуючи високі денні температури та посушливі умови, обробки посіву (підживлення і фунгіцидні) проводили у вечірні години (після 20.00), коли і температура зменшувалась та втихав вітер, тобто умови для засвоєння речовин препаратів і їх ефективність значно зростала. Така система догляду за рослинами дозволила при мінімальному застосуванні гербіцидів (Тівітус 25 в.г. - 0,045 кг/га) тримати посіви картоплі відносно чистими від бур'янів впродовж усього періоду вегетації.

Для боротьби з колорадським жуком застосовували інсектицид Антиколорад Макс з нормою витрати 0,15 л/га (проведено 4 обробки - дві останні поєднували з обробкою проти хвороб). Боротьбу з фрітофторою, макроспоріозом розпочинали при висоті рослин 15-20 см, використовуючи при цьому у 2019 році системні фунгіциди, а у 2020 році контактно системні фунгіциди Косайд 2000, ВГ та Захист (аналог Ридоміл Голд МЦ 68 з. п.) з нормою витрати відповідно 1,7 та 2,0 кг/га. Проводили послідовно 2 обробки $з$ рекомендованим інтервалом. На початку відмирання нижніх листків рослин картоплі бадилля скошували KIP-1,5. Збирання картоплі - вручну.

Статистичну обробку отриманих експериментальних даних виконували за загальноприйнятими методиками з використанням методу дисперсійного аналізу згідно методики Б. О. Доспєхова (Dospehov, 1985) з використанням прикладних програм для статичного обробітку та графрічного аналізу.

Результати. Формування насіннєвої продуктивності посівів картоплі в першу залежить від реакції сорту на умови вирощування. Ефективність застосування регуляторів росту, з метою підвищення загальної та насіннєвої продуктивності, також значною мірою залежить від біо-

Агрометеорологічні умови росту і розвитку рослин картоплі, 2019-2020 pp.

\begin{tabular}{|c|c|c|c|c|c|c|c|c|c|c|}
\hline \multirow[t]{2}{*}{ Фази розвитку } & \multicolumn{2}{|c|}{ Кількість діб } & \multicolumn{2}{|c|}{$\begin{array}{l}\text { Сума активних } \\
\text { температур, }^{\circ} \mathrm{C}\end{array}$} & \multicolumn{2}{|c|}{$\begin{array}{l}\text { Кількість } \\
\text { опадів, мм }\end{array}$} & \multicolumn{2}{|c|}{$\begin{array}{l}\text { Гідротермічний } \\
\text { коефіцієнт }\end{array}$} & \multicolumn{2}{|c|}{$\begin{array}{c}\text { Середня } \\
\text { температура } \\
\text { повітря, }{ }^{\circ} \mathrm{C}\end{array}$} \\
\hline & 2019 & 2020 & 2019 & 2020 & 2019 & 2020 & 2019 & 2020 & 2019 & 2020 \\
\hline \multicolumn{11}{|c|}{ Ранньостиглі сорти (Скарбниця, Щедрик) } \\
\hline Садіння - сходи & & & & & 35,7 & 46,0 & & & & \\
\hline Сходи - бутонізація & 24 & 25 & 475,5 & 442,5 & 13,3 & 85,1 & 0,3 & 1,9 & 23,8 & 17,7 \\
\hline Бутонізація - цвітіння & 10 & 11 & 321,0 & 276,4 & - & 1,0 & - & - & 23,7 & 25,1 \\
\hline Цвітіння - відмирання бадилля & 37 & 43 & 851,5 & 954,3 & 61,7 & 86,6 & 0,7 & 0,9 & 20,3 & 22,2 \\
\hline Всього & 91 & 99 & 1971,4 & 1928,2 & 110,7 & 218,7 & 0,5 & 1,1 & 22,2 & 19,5 \\
\hline \multicolumn{11}{|c|}{ Середньостиглі сорти (Слов'янка) } \\
\hline Садіння -сходи & & & & & 36,5 & 53,5 & & & & \\
\hline Сходи - бутонізація & 26 & 28 & 571,1 & 536,9 & 12,5 & 77,5 & 0,2 & 1,4 & 24,8 & 19,2 \\
\hline Бутонізація - цвітіння & 14 & 15 & 333,3 & 364,3 & 4,3 & 13,0 & 0,1 & 0,3 & 23,8 & 24,3 \\
\hline Цвітіння - відмирання бадилля & 39 & 40 & 961,8 & 86,9 & 61,9 & 74,6 & 0,6 & 0,8 & 20,9 & 21,7 \\
\hline Всього & 102 & 106 & 2224,7 & 2092,6 & 115,2 & 218,6 & 0,4 & 1,0 & 21,9 & 19,8 \\
\hline
\end{tabular}

Вплив стимуляторів росту при позакореневому внесенні на бульбоутворення рослин картоплі,

Таблиця 3 середнє за 2019-2020 pp.

\begin{tabular}{|c|c|c|c|c|c|}
\hline \multirow{3}{*}{ Варіанти досліджень } & \multicolumn{5}{|c|}{ Кількість бульб } \\
\hline & \multicolumn{4}{|c|}{ шт/M² } & \multirow{2}{*}{ шт./кущ } \\
\hline & $>60 \mathrm{MM}$ & $30-60$ мм & $>30 \mathrm{Mm}$ & всього & \\
\hline \multicolumn{6}{|c|}{ Скарбниця } \\
\hline 1. Без внесення (контроль) & 3,2 & 12,6 & 16,1 & 31,9 & 5,58 \\
\hline 2. Агрінос Д & 4,2 & 16,3 & 19,8 & 40,3 & 7,05 \\
\hline 3. Вегестим, РК & 4,1 & 14,7 & 16,6 & 34,8 & 6,09 \\
\hline 4. Вимпел-К ( Агролайт-У ) & 3,8 & 15,8 & 17,0 & 36,6 & 6,40 \\
\hline 5. Гумати & 4,4 & 16,8 & 19,9 & 41,1 & 7,19 \\
\hline \multicolumn{6}{|c|}{ Щедрик } \\
\hline 1. Без внесення (контроль) & 4,5 & 13,6 & 18,6 & 36,7 & 6,42 \\
\hline 2. Агрінос Д & 5,1 & 16,6 & 16,9 & 38,6 & 6,76 \\
\hline 3. Вегестим, РК & 6,5 & 16,6 & 17,3 & 40,4 & 7,07 \\
\hline 4. Вимпел-К ( Агролайт-У ) & 6,6 & 17,0 & 17,9 & 41,5 & 7,26 \\
\hline 5. Гумати & 8,2 & 18,3 & 18,3 & 44,8 & 7,84 \\
\hline \multicolumn{6}{|c|}{ Слов'янка } \\
\hline 1. Без внесення (контроль) & 3,3 & 12,3 & 13,5 & 29,0 & 5,08 \\
\hline 2. Агрінос Д & 4,2 & 13,8 & 11,9 & 29,9 & 5,24 \\
\hline 3. Вегестим, РК & 4,3 & 13,8 & 12,1 & 30,3 & 5,30 \\
\hline 4. Вимпел-К ( Агролайт-У ) & 4,1 & 12,1 & 12,7 & 30,1 & 5,26 \\
\hline 5. Гумати & 6,5 & 14,3 & 11,4 & 32,2 & 5,63 \\
\hline
\end{tabular}


логічних особливостей сортів картоплі, посіви яких були обробленні цією групою препаратів (Levin et al., 2016).

На підставі проведених досліджень встановлено, що за позакореневої обробки рослин картоплі у період вегетації регуляторами росту виявлено зростання загальної кількості бульб у кущі відносно контрольного варіанту (табл. 3) - від 0,16 до 1,61 шт/кущ і значною мірою залежало від сортової реакції на дію препарату. Так, у ранньостиглого сорту Скарбниця це зростання коливалось до 6,09-7,19 при 5,58 шт./кущ на контролі.

Реакція сорту Щедрик на застосування регуляторів росту полягала у підвищенні виходу загальної кількості бульб з куща від 6,76 до 7,84 при значенні на контролі у 6,42 шт./кущ. У сорту Слов'янка бульби фрормувалися на рівні 5,24-5,30 та 5,06 шт./кущ відповідно. Відповідно біологічна реакція сортів на застосування регуляторів росту у Щедрика та Скарбниці призвела до значного зростання кількості бульб (до 22,1 \% та 28,1 \% відповідно), в той час у сорту Слов'янка зростання було відмічене лише на рівні 3,1-4,3\%.

Структурний аналіз бульбоутворення виявив перевагу дрібної фракції картоплі всіх сортів за кількісним значенням. При позакореневих обробках рослин, не дивлячись на зростання загальної кількості бульб в кущі, відзначено зменшення кількості бульб дрібної фрракції, за виключенням варіантів у сорту Скарбниця, де кількість дрібних бульб зросла на 0,9-3,8 шт./м². За виходом насіннєвої фракції сорти на контролі мали майже однакові показники на рівні 12,0-13,5 шт./м². Застосування препаратів в посівах сорту Скарбниця позитивно влипнуло на кількість бульб з квадратного метра. Так при обробці посівів Вестимом, РК та Вимпелом-К (Агролайтом -У) було отримано 14,7-15,8 шт./M², а при обробці Агріносом Д та Гуматами 16,3-16,8 шт./м².

Фракційний склад, який склався у дослідженні в середньому за варіантами, наведено на рис. 1. Дані вказують, що на долю дрібної фрракції у варіантах без застосування препаратів приходиться в середньому 49,2 \%. Позакореневе внесення регуляторів росту зменшує частку цієї фракції на 5,0-7,6 \%. При цьому відзначено збільшення долі крупної фракції на 1,5-5,3 \% та насіннєвої фрракції - на 1,5-3,5 \%. Більший вплив на вихід насіннєвої фракції мали препарати Агрінос Д та Вегестим. Найбільша кількість крупних бульб формувалась при комплексному застосуванні Гуматів.

У розрізі сортів фракційний склад мав наступну конфігурацію (табл. 4). За проведення позакореневих обробок рослин картоплі розчинами регуляторів росту у сорту Щедрик максимальний вихід насіння (\% до загальної кількості бульб в кущі у варіанті) відмічено при застосуванні препарату Агрінос Д до 43,0 \% (+ 5,9% до контролю), у сорту Скарбниця при застосуванні препарату Вимпел-К ( Агролайт-У) - 43,1 \% (+3,5\%), у сорту Слов'янка - препаратів Агрінос Д - 46,0 \% (3,7 \%) та Вестим, РК - 45,7 \% (3,4 \%). У разі необхідності для насіннєвих цілей можливо використання крупної фрракції. За сумарною часткою крупної та насіннєвої фракцій найбільшу кількість бульб у сорту Щедрик формують росли варіанту з позакореневою обробкою посівів комплексом Гуматів - 50,1 \%, у сорту Скарбниця препаратом Вимпел-К (Агролайт-У ) - 53,6 \% та у сорту Слов'янка комплексом Гуматів - 64,7\%.

Кількісні показники приросту насіннєвої фракції (рис. 2) вказують на їх зростання при позакореневій обробці посівів регуляторами росту. Виключенням є варіант із застосуванням препарату Вимпел-К (Агролайт-У) на картоплі сорту Слов'янка. Біологічні особливості сортів значною мірою впливають на ефективність обробки регуляторами росту з метою збільшення виходу насіння з куща. Крім зазначеного сорту Слов'янка, реакція якого на внесення препарату призвела до зменшення кількості бульб відносно контролю, сорти значно різняться за приростом кількості насіннєвих бульб по кожному варіанту застосування регуляторів росту. Найбільше варіювання

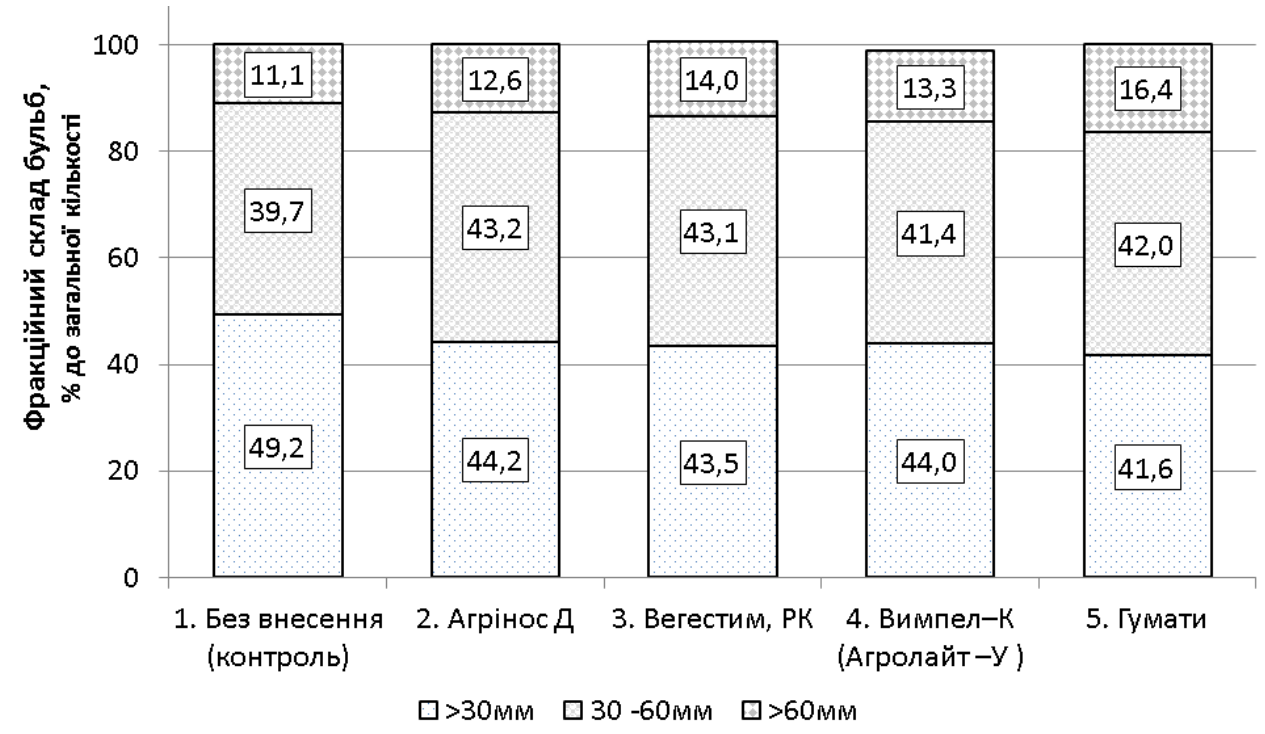

Рис. 1. Формування фракційного складу бульб в посівах картоплі залежно від позакореневої обробки посівів регуляторами росту, середнє за 2019-2020 pp. 
параметра, що досліджувався, відзначено при обробці посівів препарату Вимпел-К (Агролайт-У) - 3,6 шт./кущ. Найбільше значення зростання виходу насіння з куща за використанням препарату Агрінос Д було відзначено у рослин сорту Скарбниця 3,7 шт/кущ, у разі обробки посівів картоплі іншими регуляторами більш чуйними виявилися рослини сорту Щедрик. 3 точки зору збільшення кількості бульб насіннєвої фрракції виявилося комплексне застосування Гуматів. Відносно контрольного варіанту при обробці посівів Гуматами вихід насіння зростає у сорту Щедрик на 12,8 \%, сорту Скарбниця $13,1 \%$ та сорту Слов'янка $-6,9 \%$.
Структурний аналіз врожайності у сортів, що досліджувались, вказує на те, що коефіцієнт розмноження (вихід насіння в межах насіннєвої фракції) в контрольних варіантах коливався від 2,15 у сорту Слов'янка до 2,38 у сорту Скарбниця (табл. 5). Застосування регуляторів росту збільшувало кількість бульб, але показники середньої маси бульби значною мірою залежали від застосованих регуляторів росту.

Коливання маси середньої бульби у варіантах сорту Скарбниця було від -11,6 до 4,3%. Збільшення цього показника відзначалось при обробці препаратами Вегестим та Гуматами. У сорту Щедрик маса насіннєвої

Таблиця 4

Розподіл кількості бульб картоплі за розмірами при позакореневому внесенні регуляторів росту, середнє за 2019-2020 рр.

\begin{tabular}{|c|c|c|c|}
\hline \multirow{2}{*}{ Варіанти досліджень } & \multicolumn{3}{|c|}{ Фракційний склад бульб, \% до загальної кількості } \\
\hline & крупна, > 60 мм & насіннєва, 30-60 мм & дрібна, > 30 мм \\
\hline \multicolumn{4}{|c|}{ Скарбниця } \\
\hline 1. Без внесення (контроль) & 10,0 & 39,6 & 50,4 \\
\hline 2. Агрінос Д & 10,5 & 40,4 & 49,1 \\
\hline 3. Вегестим, РК & 11,7 & 42,4 & 47,6 \\
\hline 4. Вимпел-К ( Агролайт-У) & 10,5 & 43,1 & 46,4 \\
\hline 5. Гумати & 10,7 & 40,9 & 48,4 \\
\hline \multicolumn{4}{|c|}{ Щедрик } \\
\hline 1. Без внесення (контроль) & 12,1 & 37,1 & 50,8 \\
\hline 2. Агрінос Д & 13,3 & 43,0 & 43,6 \\
\hline 3. Вегестим, РК & 16,0 & 41,2 & 42,9 \\
\hline 4. Вимпел-К ( Агролайт-У ) & 15,8 & 40,9 & 43,3 \\
\hline 5. Гумати & 18,2 & 40,8 & 40,9 \\
\hline \multicolumn{4}{|c|}{ Слов'янка } \\
\hline 1. Без внесення (контроль) & 11,2 & 42,3 & 46,5 \\
\hline 2. Агрінос Д & 14,1 & 46,0 & 39,9 \\
\hline 3. Вегестим, РК & 14,3 & 45,7 & 40,0 \\
\hline 4. Вимпел-К ( Агролайт-У ) & 13,7 & 40,3 & 42,2 \\
\hline 5. Гумати & 20,2 & 44,4 & 35,3 \\
\hline
\end{tabular}

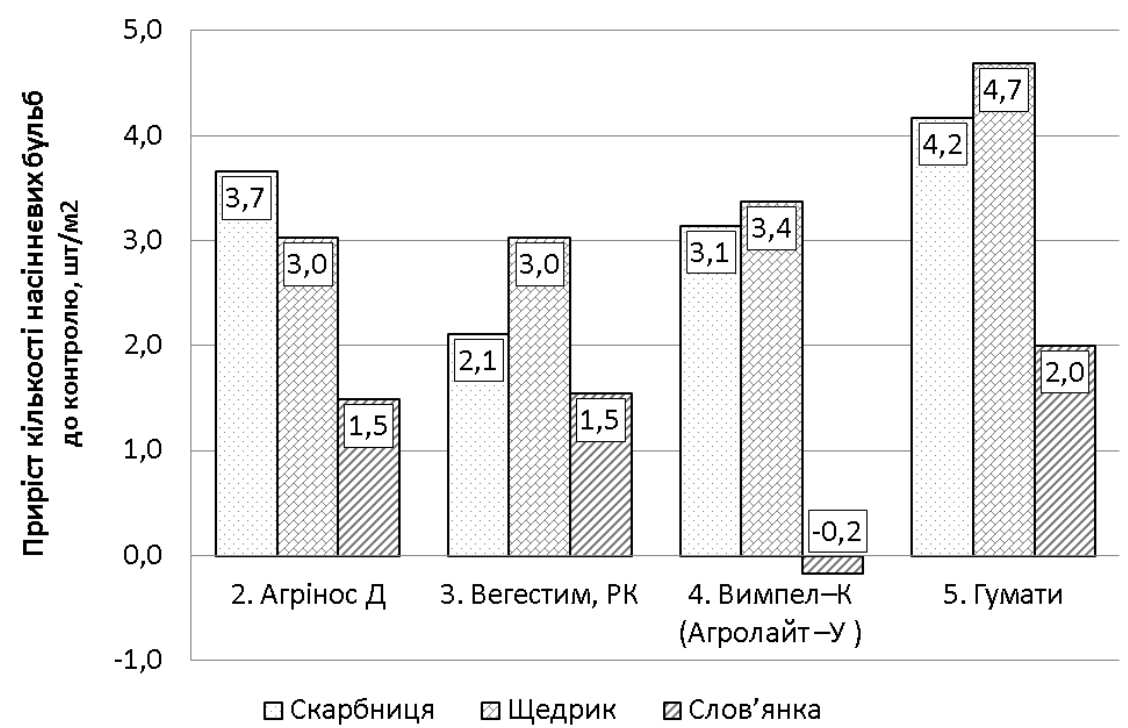

Рис. 2. Приріст кількості насіннєвих бульб до контролю при застосуванні регуляторів росту, середнє за 2019-2020 рр. 
бульби у варіантах з препаратами була на рівні контролю, або поступалась йому (-8,4-0,5\%). Сорту Слов'янка знижував масу однієї середньої насіннєвої бульби при обробці регуляторами росту відносно контрольного варіанту. Так при застосуванні Гуматів та Вегестима зниження склало 10,1 та 9,3 відповідно. Таким чином, позакоренева обробка посівів картоплі в більшості випадків призводила до зниження показника маси середньої бульби, що на пряму вплинуло на вихід посадкового матеріалу.

Враховуючи різну реакцію сортів на позакореневу обробку посіві картоплі формуванням кількості бульб та їх середньої маси, це призвело до значного варіювання насіннєвої врожайності у варіантах. Так, у сорту Скарбниця обробка Вимпелом-К призвела до зростання насіннєвої продуктивності на 9,8 \% відносно контролю, при застосуванні Гуматів зростання збільшилося до 35,6 \%. У всіх варіантах із регуляторами росту в посівах сорту Щедрик при зростанні насіннєвої врожайності варіювання значно поступалось сорту Скарбниця. Так мінімальне зростання врожайності у варіанті із Венестимом склало 16,0 \%, максимальне значення відзначено у варіанті з Гуматами - 29,0 \%. Сорт Слов'янка відзначився меншою реакцією на обробку посівів регуляторами росту (зростання врожайності насіннєвої фракції склало 3,2-14,8 \%). Найбільший приріст відзначено у варіантах з Вимпел-К (12,0 \%) та Агрінос Д (14,9 \%). Максимальна насіннєва врожайність в розрізі сортів була в варіантах 3 наступним застосуванням препаратів: Скарбниця - Гумати (8,31 т/га); Щедрик - Агрінос Д (8,78 т/га) та Гумати (8,80 т/га); Слов'янка - Агрінос Д (6,89 т/га).

Вихід насіннєвої фракції значною мірою коливався від біологічної реакції сортів на обробку посівів регуляторами росту. Відносно контролю, у сорту Скарбниця насіннєва фракція в структурі врожайності зростала

від 0,4 \% (Агрінос Д) до 4,5 \% (Вестим, РК). В посівах сорту Щедрик варіант із застосуванням Гуматів відсоток насіннєвої фракції знижувався на 2,4 \%, при Вестиму, РК структурні показники були на рівні контролю показники. Обробка Вимпелом-К (Агролайт-У ) давала значення близькими до контролю (+ 0,4 \%). Лише за обробкою регулятором росту Агрінос Д відзначено зростання на 5,8 \%. Вихід насіннєвої фрракції у крупнобульбового сорту Слов'янка майже у всіх варіантах знижувався від 0,5 \% (Вестим, РК) до 6,7 \% (Гумати). Зростання відзначено лише у варіанті з обробкою посівів Агрінос Д.

Обговорення. Проблема постачання та забезпечення господарств всіх форм власності високоякісним насіннєвим матеріалом картоплі високих генерацій в Україні $€$ досить гострою. Підвищення виходу насіння з одиниці площі внаслідок застосування стимуляторів росту $є$ одним зі шляхів визначеної проблеми. Такій підхід $€$ достатньо вивчений (Murashev et al., 2020; Ekin, 2019; Vladimirov et al., 2019), але значне різноманіття препаратів, чутливість їх до умов вирощування картопля, а також біологічні реакції сорту (Neverov et al., 2018; Magomedov et al., 2021) фрормують широке поле для досліджень впливу регуляторів росту на формування врожайності бульб та вихід насіння з одиниці площі.

В результаті досліджень встановлено, що в умовах північно-східного Лісостепу встановлений позитивний вплив всіх препаратів, що вносилися, на формування насіннєвої продуктивності. Врожайність значною мірою залежала від сортових особливостей. Середній у сорту ваговий вихід насіння в врожайності бульб складав від $40,5 \%$ у сорту Щедрик до 45,9 \% у сорту Скарбниця. Застосування Гуматів в більшості випадків значно збільшували насіннєву продуктивність, але в структурі врожайності їх вага значно поступалася контролю.

Таблиця 5

Структурні показники насіннєвої фракції картоплі різних сортів, сформовані в залежності від обробки посівів регуляторами росту, середнє за 2019-2020 рр.

\begin{tabular}{|c|c|c|c|c|c|c|}
\hline \multirow{2}{*}{$\begin{array}{c}\text { № } \\
\text { варіантів }\end{array}$} & \multirow{2}{*}{ Використані препарати } & \multirow{2}{*}{$\begin{array}{c}\text { Кількість } \\
\text { насіннєвих } \\
\text { бульб } \\
\end{array}$} & \multirow{2}{*}{$\begin{array}{l}\text { Вага бульб } \\
\text { з1 куща, кг }\end{array}$} & \multirow{2}{*}{$\begin{array}{c}\text { Маса } \\
1 \text { середньої } \\
\text { бульб, г }\end{array}$} & \multicolumn{2}{|c|}{$\begin{array}{c}\text { Вихід насіннєвої фрракці } \\
\text { по масі бульб }\end{array}$} \\
\hline & & & & & $\%$ & т/га \\
\hline \multicolumn{7}{|c|}{ Скарбниця } \\
\hline 1 & Без внесення (контроль) & 2,38 & 0,12 & 55,2 & 44,4 & 6,13 \\
\hline 2 & Агрінос Д & 2,91 & 0,15 & 54,3 & 44,8 & 7,30 \\
\hline 3 & Вегестим, РК & 2,91 & 0,15 & 56,5 & 48,9 & 7,29 \\
\hline 4 & Вимпел-К (Агролайт -У) & 2,97 & 0,13 & 48,8 & 44,6 & 6,73 \\
\hline 5 & Гумати & 3,20 & 0,17 & 57,6 & 46,9 & 8,31 \\
\hline \multicolumn{7}{|c|}{ Щедрик } \\
\hline 1 & Без внесення (контроль) & 2,21 & 0,14 & 59,6 & 39,7 & 6,82 \\
\hline 2 & Агрінос Д & 2,85 & 0,18 & 59,9 & 45,5 & 8,78 \\
\hline 3 & Вегестим, РК & 2,58 & 0,16 & 54,6 & 39,7 & 7,91 \\
\hline 4 & Вимпел-К (Агролайт -У) & 2,76 & 0,16 & 56,8 & 40,1 & 8,23 \\
\hline 5 & Гумати & 2,94 & 0,18 & 56,7 & 37,3 & 8,80 \\
\hline \multicolumn{7}{|c|}{ Слов'янка } \\
\hline 1 & Без внесення (контроль) & 2,15 & 0,11 & 49,8 & 42,4 & 5,30 \\
\hline 2 & Агрінос Д & 2,41 & 0,14 & 57,2 & 43,6 & 6,89 \\
\hline 3 & Вегестим, РК & 2,42 & 0,12 & 51,4 & 41,1 & 6,16 \\
\hline 4 & Вимпел-К (Агролайт -У) & 2,12 & 0,11 & 55,8 & 41,9 & 5,70 \\
\hline 5 & Гумати & 2,50 & 0,12 & 51,9 & 35,7 & 6,21 \\
\hline
\end{tabular}


Слід зазначити, що посадковий матеріал картоплі більшою мірою доцільно розглядати не з точки зору вагових показників, а кількості бульб придатних для висадки. Як показали дослідження, застосування стимуляторів росту фрракційний склад під дією препаратів у середньому по досліду збільшувався в сторону насіннєвих бульб від 1,7 \% (Вимпел-К) до 3,5 \% (Агрінос Д) та у крупної фрракції від 1,5% (Агрінос Д) до 5,3 \% (Гумати).

В розрізі сортів найбільшу прибавку насіннєвих бульб формували посіви, які були оброблені Гуматами. Сортом, який виявив стійкість до застосування препаратів, була Слов'янка. Максимальне збільшення коефіцієнту розмноження у нього відзначалось при обробці
Гуматами $(2,0)$, а на застування Вимпел-К (Агролайт-У) рослини зменшили показник виходу насіннєвих бульб відносно контролю.

Висновки. У результаті проведених досліджень встановлено, що використання регуляторів росту в посівах картоплі в умовах північно-східного Лісостепу України позитивно впливає на збільшення насіннєвої продуктивності, як у вагових, так і кількісних параметрах. При застосуванні препаратів виявлена різна реакція сортів на вид препарату. Найбільш впливовим на формування посадкового матеріалу виявилась система обробки посівів із застосуванням комплексу Гуматів. Меншою мірою на позакореневу обробку посівів регуляторами росту реагував сорт Слов'янка.

\section{Бібліографічні посилання:}

1. Agaronjan, A. G., Sargisjan, S. M., \& Ter-Baljan, N. G. (2020). Sovmestnoe primenenie gerbicidov i stimuljatora rosta na poljah kartofelja.[ Co-application of herbicides and growth stimulants in potato fields] Zashhita i karantin rastenij, 12, $23-24$.

2. Araujo, F. F., Santos, M. N., Costa, L. C., Moreira, K. F., Araujo, M. N., Martinez, P. A., \& Finger, F. L. (2019). Changes on potato leaf metabolism and anatomy induced by plant growth regulators. Journal of Agricultural Science, 11(7), 139-147. doi: 10.5539/jas.v11n7p139

3. Atanaw, T. (2021). Israel Zewide. Fertility Management on Potato (Solanum tubersumL.). Crop. Research \& Reviews: Journal of Crop Science and Technology, 10(1), 33-46. doi: 10.37591/RRJoCST

4. Barabolja, O. V., \& Ljashenko, €. S. (2018). Osoblivosti viroshhuvannja ta zberigannja kartopli.[Features of growing and storing potatoes] Zbalansovanij rozvitok agroekosistem Ukraïni: Suchasnij pogljad ta innovaciï, 132-135.

5. Barkovs'kij, O. M., \& Kucenko, V. S. (1999). Vpliv peredposadkovogo obrobitku bul'b zahisnostimuljujuchimi preparatami na urozhaj kartopli. [The effect of pre-planting treatment of tubers with protective stimulants on the potato crop]. Kartopljarstvo, 29, 133-137.

6. Baybulatov, T. S., Magaramov, I. B., Chabibov, S. R., Islamov, M. G., \& Minatullaev, S. M. (2018). Results of the Research on the Topic of Ecologically Safe Technology of Planting Potatoes with a Help of Liquid Organic Fertilizers. practice, 1(2), 3, 890-894.

7. Butenko, $€$. Ju. (2018). Stvorennja vihidnogo materialu dlja selekciï kartopli pid diєju chinnikiv himichnogo mutagenezu. [Creation of source material for potato selection under the influence of chemical mutagenesis factors]. Suchasni tendenciï rozvitku nauki, 10-12.

8. Bilins'ka, O. M., Kul'ka, V. P., Samec', N. P., \& Golod, R. M. (2021). Vpliv zastosuvannja preparatu Al'bit na formuvannja nasinnєvoï produktivnosti dobazovogo materialu kartopli. [The influence of application of the preparation Albit on formation of seed productivity of supplemental potatoe material]. Visnik agrarnoï nauki Prichornomor'ja, 2. ,71-79. doi: 10.31521/2 313-092X/2021-2(110)-9

9. Dospehov, B. A. (1985). Metodika polevogo opyta [Methods of field experience], Агропромиздат, Москва, 416.

10. Ekin, Z. (2019). Integrated use of humic acid and plant growth promoting rhizobacteria to ensure higher potato productivity in sustainable agriculture. Sustainability, 11(12), 3417.

11. Grossi, C. E. M., Fantino, E., Serral, F., Zawoznik, M. S., Fernandez Do Porto, D. A., \& Ulloa, R. M. (2020). Methylobacterium sp. $2 \mathrm{~A}$ is a plant growth-promoting rhizobacteria that has the potential to improve potato crop yield under adverse conditions. Frontiers in plant science, 11, 71. doi: 10.3389/fpls.2020.00071

12. Juzjuk, O. Produktivnist' nasinn€voï kartopli zalezhno vid udobrennja ta zastosuvannja reguljatoriv rostu v umovah zroshennja pivdnja Ukraïni [Productivity of seed potatoes depending on fertilizer and application of growth regulators in the conditions of irrigation of the south of Ukraine]. Zroshuvane zemlerobstvo, 68, 175-179.

13. Kabanec', V. M. Muzika, L. P., \& German, B. O. (2013). Viroshhuvannja nasinnevoï i prodovol'choï kartopli na prisadibnih diljankah, $v$ fermers'kih ta reformovanih gospodarstvah [Growing of seed and food potatoes on homesteads, in farms and reformed farms], 23-28.

14. Koltunov, V.A. Vajceshina, N.I., Borodaj, V.V., \& Karmazina, L.€. (2012). Vpliv obrobki biopreparatami na vrozhajnist', tovarnist', strukturu ta zberezhenist' bul'b kartopli zalezhno vid umov viroshhuvannja i stroku sadinnja v zoni Polissja Ukraïni. [Influence of treatment with biological products on yield, marketability, structure and safety of potato tubers depending on growing conditions and planting period in the Polissya region of Ukraine]. Kartopljarstvo Ukraïni, 1-2(26-27), 35-43.

15. Korshunov, A. V., Simakov, E. A., Lysenko, Ju. N., Anisimov, B. V., Mitjushkin, A. V., \& Gaitov, M. Ju. (2018). Aktual'nye problemy i prioritetnye napravlenija razvitija kartofelevodstva.[Actual problems and priority directions of innovative development of potato breeding] Dostizhenija nauki i tehniki APK, 32(3), 12-20. doi: 10.24411/0235-2451-2018-10303

16. Kovalenko, O. A., \& Olijnik, T. M. (2016) Zastosuvannja riznih agrotehnichnih prijomiv z vikoristannjam reguljatora rostu roslin Vimpel pri rozmnozhenni ozdorovlenih in Vitro roslin kartopli v umovah pivnichno-shidnogo Lisostepu Ukraïni.[ Application of various agrotechnical methods with the use of the plant growth regulator Vimpel in the propagation of healthy potato plants in Vitro in the conditions of the north-eastern Forest-Steppe of Ukraine]. Pidvishhennja efektivnosti virobnictva sil's'kogospodars'koï produkciï v pivnichno-shidnomu regioni Ukraïni, 141-145.

17. Kovalenko, O. A., Kravchenko, O. A., Sharana, M. G., \& Kalic'kij P. F. (2007) Zastosuvannja reguljatoriv rostu roslin u suchasnij tehnologiï viroshhuvannja kartopli [Application of plant growth regulators in modern potato growing technology]. Kartopljarstvo Ukraïni, 3-4(8-9), 9. 
18. Kucenko, V. S., Osipchuk, A. A., Podgaec'kij, A. A., \& Kononuchenko, V. V. (2002) Metodichni rekomendaciï shhodo provedennja doslidzhen' z kartopleju. [Methodical recommendations for research with potatoes]. Institut kartopljarstva, Nemisha€ve, 482.

19. Levin, V. I., Petruhin, A. S., \& Antipkina, L. A. (2016). Sortovaja reakcija kartofelja na vozdejstvie reguljatorov rosta. [Varietal reaction of potato the effect of growth regulators] Vestnik Rjazanskogo gosudarstvennogo agrotehnologicheskogo universiteta im. PA Kostycheva, 4 (32), 19.

20. M'jalkovs'kij, R., Bezvikonnij, P., \& Potaps'kij, Ju. (2021). Urozhajnist' kartopli sortu Miroslava zalezhno vid rivnja mineral'nogo zhivlennja i gustoti sadinnja $v$ umovah zahidnogo Lisostep [Yield of Myroslav potatoes depending on the level of mineral nutrition and planting density in the conditions of the Western forest steppe]. Nauka XXI st.: vikliki ta perspektivi, 2, 135-145. doi: 10.37406/sXXIcp.2021.v2.135.

21. Magomedov, R., Musaev, M., Magomedova, A., Musaeva, Z., \& Kuramagomedov, A. (2021) Vlijanie biogumusa i reguljatorov rosta na urozhajnost' sortov rannego kartofelja v oroshaemyh uslovijah Dagestana. [Influence of vermicompost and growth regulators on the yield of early potato varieties under irrigated conditions in Dagestan]. Izvestija KabardinoBalkarskogo nauchnogo centra RAN., 2, 50-59. doi: 10.35330/1991-6639-2021-2-100-50-59

22. Milyokhin, A. V., Bakunov, A. L., Dmitrieva, N. N., Rubtsov, S. L., \& Shevchenko, S. N. (2020). Development rate of meristem potato plants (Solanum tuberosum) in vitro under the influence of biologically active product nano silicon. Research on Crops, 21(2), 291-295.

23. Moloc'kij, M. Ja., Fedorchuk, Ju .V., \& Zhitnec'kij, K. V. (2009). Produktivnist' kartopli za kompleksnogo zastosuvannja dobriv i reguljatoriv rostu roslin v umovah central'nogo Lisostepu Ukraïni [Productivity of potatoes with complex application of fertilizers and plant growth regulators in the conditions of the central Forest-steppe of Ukraine].Kartopljarstvo Ukraïni., №3-4 (16-17), 40-49.

24. Morozov, V. V., Fedorova, Y. N., Telpuk, M. B., \& Fedorova, L. N. (2018). Factors of Increasing the Productivity of Potatoes In vitro. Advances in Engineering Research, 151, 712-716

25. Muleta, H. D., \& Aga, M. C. (2019). Role of nitrogen on potato production: a review. Journal of Plant Sciences, 7(2), 36-42. doi: 10.11648/j.jps.20190702.11

26. Murashev, S. V., Kiru, S. D., Verzhuk, V. G., \& Pavlov, A. V. (2020). Potato plant growth acceleration and yield increase after treatment with an amino acid growth stimulant. Agronomy Research 18(2), 494-506. doi: 10.15159/ar.20.036

27. Medvedeva, I. O., \& Kostjukevich, T. K. (2020). Osoblivosti ta perspektivi viroshhuvannja kartopli v Poltavs'kij oblasti. Materiali vseukraïns'koï naukovo-praktichnoï konferenciï «Rubinovs'ki chitannja», 26-27.

28. Neverov, A. A., Voskobulova, N. I., \& Vereshhagina, A. S. (2018). Vlijanie obrabotki semjan reguljatorom rosta rastenij Mival-Agro na formirovanie urozhaja zerna kukuruzy v razlichnyh pogodnyh uslovijah [Effect of seed treatment with growth regulator Mival-Agro on the formation of corn grain yield in various weather conditions]. Zhivotnovodstvo $\mathrm{i}$ kormoproizvodstvo, 101(2), 209-217.

29. Polishhuk, M. I. (2021). Vpliv sposobiv ta strokiv zastosuvannja reguljatora rostu Emistim S na elementi produktivnosti sortiv kartopli v umovah Lisostepu Pravoberezhnogo.[The influence of methods and terms of application of the growth regulator Emistim $\mathrm{C}$ on the elements of productivity of potato varieties in the conditions of the Forest Steppe] Sciences of Europe, (72-2), 3-11.

30. Prishhepenko, E. A. (2020). Vlijanie biopreparatov kompleksnogo dejstvija na urozhajnost' kartofelja. [Formation of potato crop using complex biological products in the conditions of the volga region of the Republic of Tatarstan] Innovacionnye razrabotki i cifrovizacija v APK RF, 93-99.

31. Semenchuk, V. (2018). Produktivnist' kartopli zalezhno vid zastosuvannja reguljatora rostu roslin Agat-25K [Potato productivity depending on the use of plant growth regulator Agate-25K]Zahist i karantin roslin, 64 .

32. Smirnova, T., Temereva, I., Panov, S., \& Stepanova, T. (2021). The Efficiency of Pre-Sowing Seed Treatment with Trace Element Solutions. KnE Life Sciences, 593-600. doi: 0000-0002-1123-0472

33. Trembic'ka, O., Klimenko, T., \& Fedorchuk, S. (2020). Vpliv reguljatoriv rostu na jakist' bul'b kartopli.[Influence of

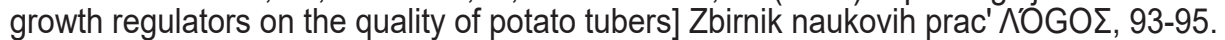

34. Uromova, I. P., Kozlov, A. V., Koposova, N. N., Volkova, A. V., Vershinina, I. V., Avdeev, Y. M., \& Tesalovsky, A. A. (2019). Growth regulators as a factor of optimizing the biometric parameters and productivity of improved potatoes in nursery conditions. International Journal of Innovative Technology and Exploring Engineering, 8(7), 756-758.

35. Vladimirov, V. P., Mostjakova, A. A., Egorov, L. M., \& Agiev, F. F. (2019). Produktivnost' kartofelja v zavisimosti ot sposoba primenenija reguljatora rosta i raschetnom fone mineral'nogo pitanija na seroj lesnoj pochve lesostepi Srednego Povolzh'ja. [Potato productivity depending on the method of application of growth regulator and calculated background of mineral nutrition on the gray forest steppe soil of Middle Volga region]. Vestnik Kazanskogo gosudarstvennogo agrarnogo universiteta, 14(S4-1), 21-26. doi: 10.12737/2073-0462-2020-21-26

36. Wróbel, S., Kęsy, J., \& Treder, K. (2017). Effect of growth regulators and ethanol on termination of dormancy in potato tubers. American Journal of Potato Research, 94(5), 544-555.

Kabanets V. M., Doctor (Agricultural Sciences), Associate Professor, Director, Institute of Agriculture of the North-East of NAAS of Ukraine, Sad, Ukraine

Onychko V .I., PhD (Agricultural Sciences), Associate Professor, Sumy National Agrarian University, Sumy, Ukraine

Muzika L .P., PhD (Agricultural Sciences), Senior Researcher, Institute of Agriculture of the North-East of NAAS of Ukraine, Sad, Ukraine

Berdin S. I., PhD (Agricultural Sciences), Associate Professor, Sumy National Agrarian University, Sumy, Ukraine Variety response to the formation of the yield of clubs when treating potato crops with growth regulators

Potato growing is almost the only branch of the agro-industrial complex of Ukraine, the production volumes of which have not changed significantly during the last 70 years. At present, about $98 \%$ of total potato production is grown on small farms, homesteads and cottages, which makes its adjustments to the technology of cultivation. 
Annual potato areas in Ukraine are 1.4-1.5 million ha, and gross production of 18-20.5 million $t$ - about $6 \%$ of world production (fifth in the world after China, Russia, India and the United States) at yield 12.0-13.9 t/ha, which is much lower than the biological capacity of the crop. The main reasons for low potato yields are: poor quality of planting material (violation of the principle of varietal renewal and timely varietal replacement), non-compliance with crop rotation, lack and inefficient use of fertilizers, plant protection products, non-compliance with basic technology conditions. The main areas of increasing yields and potato production are: improving cultivation technology, the main link of which is a clear system of seed production, introduction into the production of new varieties, varietal farming techniques and the use of high-yielding planting tubers.

The quality of seed material of any crop is the basis of its yield. Given the high cost of planting potato tubers, increasing the reproduction rate of high-generation seeds is a factor in reducing the cost of planting material. The use of growth stimulants allows not only to increase the yield of seed tubers per hectare, but also to solve it in an environmentally friendly way. Given the significant number of growth stimulating drugs and their sensitivity to soil and climatic conditions in the case of application, it is important to conduct a wide range of zonal studies to select the most effective growth stimulants.

The biological reaction of Skarbnytsia, Shchedryk, Slovyanka varieties to foliar treatment of potato crops with growth regulators Agrinos D, Vegestim, RK, Vimpel-K (Agrolight-U), humate (Gumifild BP-18, Fulvital Plus) was studied in the researches carried out at the Institute of Agriculture of North-East of NAAS of Ukraine. The object of research were the processes of formation of seed productivity of the culture under the action of these drugs. It is determined that in the conditions of the north-eastern Forest-Steppe the positive influence of all investigated drugs on the formation of seed productivity is established. Peculiarities of biological reactions of varieties to the formation of components of seed productivity are revealed. The average weight yield of seed tubers was from $40.5 \%$ in the variety Shchedryk to $45.9 \%$ in the variety Skarbnytsia. The use of humates in most cases significantly increased seed productivity, but in the structure of yield, their weight was much lower than control.

It should be noted that the planting material of potatoes is more appropriate to consider not in terms of weight, but in terms of the number of tubers suitable for planting. In structural terms, without crops treatment with growth-stimulating drugs, the tubers of the small fraction average $49.2 \%$ of the total. Foliar application of growth regulators reduces the share of this fraction by $5.0-7.6 \%$, while the fraction of large tubers increases by $1.5-5.3 \%$, and seed tubers - by $1.5-3.5 \%$. Agrinos $D$ and Vegestim had the greatest effect on the yield of the seed fraction. In terms of varieties with the use of growth stimulants, the fractional composition on average in the experiment increased in the direction of seed tubers from $1.7 \%$ (Vimpel-K) to $3.5 \%$ (Agrinos D). Despite the fact that the biological characteristics of varieties significantly affect the efficiency of treatment with growth regulators to increase seed yield from the potato bush, it was found that in terms of varieties the largest increase of seed tubers formed crops that were treated with humates. The increase of the reproduction coefficient of the varieties Skarbnytsia and Shchedryk was determined by 4.2-4.7 pieces/bush, respectively. The Slovyanka variety was the least reactive to the use of drugs. The maximum increase in its reproduction rate was observed when treated with Humates (2.0), and when using Vimpel - K (Agrolight-U) the plants reduced the yield of seed tubers relative to control.

As a result of the research it is natural to generalize that the use of growth regulators in potato crops in the conditions of the north-eastern Forest-Steppe has a positive effect on the increase of seed productivity, both in weight and in quantitative parameters. When using drugs revealed a different reaction of varieties to the type of drug. The most influential on the formation of planting material was the system of crop treatment using the complex of Humates. The Slovyanka variety reacted to a lesser extent to foliar treatment of crops with growth regulators.

Key words: potatoes, yield, seed fractions, number of tubers, mass of tubers. 